DOI: 10.1515/amm-2017-0015

T. WEQGRZYN** ${ }^{*}$, J. PIWNIK**, D. HADRYŚ***, Ł. WSZOŁEK $* * * *$

\title{
LOW ALLOY STEEL STRUCTURES AFTER WELDING WITH MICRO-JET COOLING
}

\begin{abstract}
The paper focuses on low alloy steel after innovate welding method with micro-jet cooling. Weld metal deposit (WMD) was carried out for welding and for MIG and MAG welding with micro-jet cooling. This method is very promising mainly due to the high amount of AF (acicular ferrite) and low amount of MAC (self-tempered martensite, retained austenite, carbide) phases in WMD. That structure corresponds with very good mechanical properties, ie. high impact toughness of welds at low temperature. Micro-jet cooling after welding can find serious application in automotive industry very soon. Until that moment only argon, helium and nitrogen were tested as micro-jet gases. In that paper first time various gas mixtures (gas mixtures $\mathrm{Ar}-\mathrm{CO}_{2}$ ) were tested for micro-jet cooling after welding.
\end{abstract}

Keywords: welding, micro-jet, impact toughness, steel

\section{Introduction}

New technologies are constantly being created for the production [1-6]. It has recently been invented welding with micro-jet cooling. Micro-jet technology gives chance to obtain weld that corresponds with much better mechanical properties (especially impact toughness of WMD) compared with classic welding method [7-9]. Good mechanical properties of weld correspond respectively with low-nitrogen and low-oxygen processes. Amount of nickel and molybdenium also have strong influence on metallographic structure because of the influence on acicular ferrite (AF) formation [10-12]. Amount of AF must be treated as the most beneficial structure in low alloy steel WMD that directly corresponds with high impact toughness of weld [11-12].

Even having the most optimal inclusion parameters in weld it is only possible to get maximal $55 \%$ of $\mathrm{AF}$ in weld, but never more (Fig. 1).

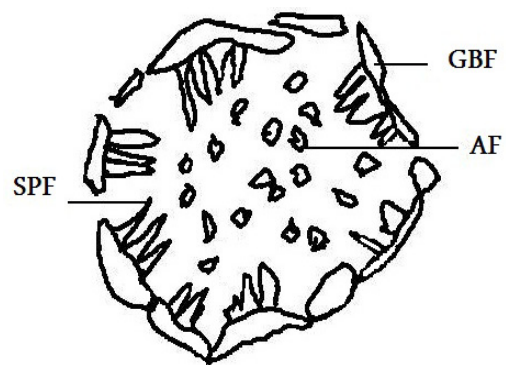

Fig. 1. Typical structure of low Alloy weld. AF - acicular ferrite, GBF - grain boundary ferrite, SPF - side plate ferrite) [1]
Micro-jet cooling just after welding gives a new chance to increase seriously high amount of AF in weld and consequently micro-jet cooling effects on impact toughness of weld [1-3]. The micro-jet cooling was tested for low alloy steel with various micro-jet parameters.

\section{Aim and plan of research}

It was decided to investigate the properties of the material, depending on the parameters of the process. The present paper aims at outlining micro-jet innovations only in MIG and MAG welding process. The weld metal deposit was prepared by welding with micro-jet cooling with varied gas mixtures for both MIG/MAG welding processes with micro-jet cooling. To obtain various amount of acicular ferrite in weld during tested welding process, the micro-jet injector was installed. Main parameters of micro-jet cooling were slightly varied:

- cooling steam diameter was varied (between: $40 \mu \mathrm{m}$ and $50 \mu \mathrm{m})$,

- gas pressure was varied (between: 0.4 $\mathrm{MPa}$ and 0.5 $\mathrm{MPa}$ ),

- micro-jet gases were varied (between: gas mixture of $90 \%$

Ar and $10 \% \mathrm{CO}_{2}$, gas mixture of $79 \% \mathrm{Ar}$ and $21 \% \mathrm{CO}_{2}$ ).

$\mathrm{MIG} / \mathrm{MAG}$ welding processes based on two shielded gases, respectively argon (for $\mathrm{MIG}$ ) and gas mixture of $79 \% \mathrm{Ar}$ and $21 \% \mathrm{CO}_{2}$ (for MAG). Figure 2 illustrates montage of welding head and micro-jet injector.

\footnotetext{
* THE SILESIAN UNIVERSITY OF TECHNOLOGY, FACYLTY OF TRANSPORT, 8 KRASIŃKIEGO STR., 40-019 KATOWICE, POLAND

** BIALYSTOK UNIVERSITY OF TECHNOLOGY, MECHANICAL FACULTY, 45C WIEJSKA STR., 16-351 BIAŁYSTOK, POLAND

*** UNIVERSITY OF OCCUPATIONAL SAFETY MANAGEMENT IN KATOWICE, 8 BANKOWA STR., 40-007 KATOWICE, POLAND

**** OŚRODEK SZKOLEŃ ZAWODOWYCH DIAGNO-TEST SP. Z O. O., 72 ŚWIERCZYNY STR., 41-400 MYSŁOWICE, POLAND

\# Corresponding author: tomasz.wegrzyn@polsl.pl
} 


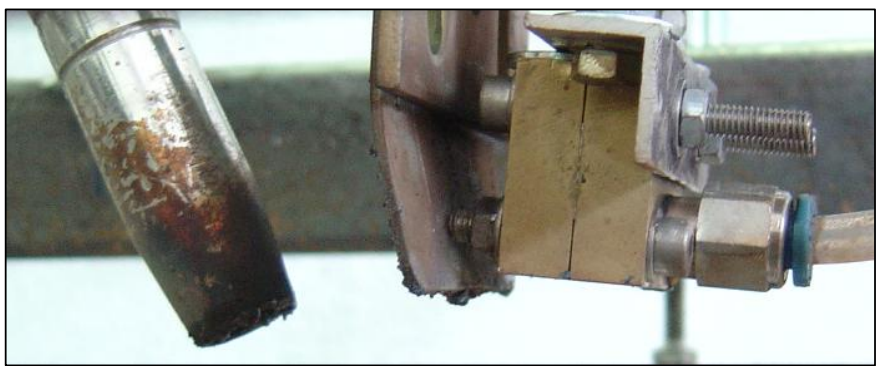

Fig. 2. Montage of welding head and micro-jet injector

\section{Materials to research}

The basic material to research was $\mathrm{S} 355 \mathrm{~J} 2 \mathrm{G} 3$ steel. Various welds of standard MIG/MAG welding were compared firstly without innovative micro-jet cooling technology. A typical weld metal deposit had rather similar chemical composition in all tested cases (Table 1). Weld metal deposit was prepared by welding with micro-jet cooling with varied gas mixtures (gas mixtures $\mathrm{Ar}-\mathrm{CO}_{2}$ ) with changing another micro-jet parameter (gas pressure). The main data about parameters of welding were shown in table 1.

TABLE 1

Parameters of welding process

\begin{tabular}{|c|c|c|}
\hline \hline No. & Parameter & Value \\
\hline 1. & Diameter of wire & $1.2 \mathrm{~mm}$ \\
\hline 2. & Standard current & $220 \mathrm{~A}$ \\
\hline 3. & Voltage & $24 \mathrm{~V}$ \\
\hline 4. & Shielding MIG welding gas & $\mathrm{Ar}$ \\
\hline 5. & $\begin{array}{c}\text { Shielding MAG welding gas } \\
\text { mixture }\end{array}$ & $\mathrm{Ar}$ and $21 \% \mathrm{CO}_{2}$ \\
\hline 5. & micro-jet cooling gas mixtures & $\begin{array}{c}1.79 \% \mathrm{Ar} / 21 \% \mathrm{CO}_{2} \\
2.90 \% \mathrm{Ar} / 10 \% \mathrm{CO}_{2}\end{array}$ \\
\hline 6. & micro-jet gas pressure & $0.4 \mathrm{MPa}$ \\
\hline 7. & steam diameter of micro-jet gas & $40 \mu \mathrm{mPa}, 50 \mu \mathrm{m}$ \\
\hline
\end{tabular}

\section{Results and discussion}

There were mainly tested and compared welds of standard MIG/MAG welding with micro-jet technology with various micro-jet gases mixtures. A typical weld metal deposit had rather similar chemical composition in all tested cases (Tables 2-3).

TABLE 2

Chemical composition of WMD after MIG process

\begin{tabular}{|c|c|c|}
\hline \hline No. & Element & Amount \\
\hline 1. & $\mathrm{C}$ & $0.08 \%$ \\
\hline 2. & $\mathrm{Mn}$ & $0.77 \%$ \\
\hline 3. & $\mathrm{Si}$ & $0.39 \%$ \\
\hline 4. & $\mathrm{P}$ & $0.016 \%$ \\
\hline 5. & $\mathrm{~S}$ & $0.017 \%$ \\
\hline
\end{tabular}

TABLE 3

Chemical composition of WMD after MAG process

\begin{tabular}{|c|c|c|}
\hline \hline No. & Element & Amount \\
\hline 1. & $\mathrm{C}$ & $0.08 \%$ \\
\hline 2. & $\mathrm{Mn}$ & $0.79 \%$ \\
\hline 3. & $\mathrm{Si}$ & $0.41 \%$ \\
\hline 4. & $\mathrm{P}$ & $0.017 \%$ \\
\hline 5. & $\mathrm{~S}$ & $0.018 \%$ \\
\hline
\end{tabular}

Various micro-jet parameters had some influence on intensively cooling conditions but did not have greater influence on chemical WMD composition.

Metallographic structure of WMD was carried out after chemical analyses of WMD (taken only for MIG processes). Very precisely acicular ferrite (AF) and MAC phases (self-tempered martensite, retained austenite, carbide) content were analyzed. Examples of the results of the metallographic structure analysis are shown in table 4.

TABLE 4

Acicular ferrite and MAC phases in WMD after MIG welding with various micro-jet parameters

\begin{tabular}{|c|c|c|c|c|}
\hline \hline $\begin{array}{c}\text { Micro-jet } \\
\text { gas }\end{array}$ & $\begin{array}{c}\text { Micro-jet } \\
\text { gas pressure } \\
{[\mathbf{M P a}]}\end{array}$ & $\begin{array}{c}\text { steam diameter } \\
\text { of micro-jet } \\
\text { gas [ } \boldsymbol{\mu} \mathbf{m}]\end{array}$ & $\begin{array}{c}\text { MAC } \\
\text { phases } \\
{[\%]}\end{array}$ & $\begin{array}{c}\text { Acicular } \\
\text { ferrite } \\
{[\%]}\end{array}$ \\
\hline- & - & - & 3 & 45 \\
\hline $79 \% \mathrm{Ar} / 21 \% \mathrm{CO}_{2}$ & 0.4 & 40 & 4 & 64 \\
\hline $79 \% \mathrm{Ar} / 21 \% \mathrm{CO}_{2}$ & 0.5 & 40 & 4 & 60 \\
\hline $90 \% \mathrm{Ar} / 10 \% \mathrm{CO}_{2}$ & 0.4 & 40 & 3 & 67 \\
\hline $90 \% \mathrm{Ar} / 10 \% \mathrm{CO}_{2}$ & 0.5 & 40 & 3 & 70 \\
\hline $79 \% \mathrm{Ar} / 21 \% \mathrm{CO}_{2}$ & 0.4 & 50 & 4 & 62 \\
\hline $79 \% \mathrm{Ar} / 21 \% \mathrm{CO}_{2}$ & 0.5 & 50 & 4 & 57 \\
\hline $90 \% \mathrm{Ar} / 10 \% \mathrm{CO}_{2}$ & 0.4 & 50 & 3 & 63 \\
\hline $90 \% \mathrm{Ar} / 10 \% \mathrm{CO}_{2}$ & 0.5 & 50 & 3 & 66 \\
\hline
\end{tabular}

Analyzing tables 4 it is easy to deduce that both MIG and MAG welding with with micro-jet gas mixture of $90 \% \mathrm{Ar} / 10 \%$ $\mathrm{CO}_{2}$ be treated as a good option. Amount of acicular ferrite in WMD after MIG welding without micro-jet cooling was only on the level of $45 \%$. Amount of acicular ferrite in WMD after MIG welding with micro-jet cooling was always on much higher level in range $57 \%-70 \%$. It is also shown that micro-jet gas pressure after MIG and MAG welding should be on the level of $0.5 \mathrm{MPa}$ and steam diameter of micro-jet cooling gas should be on the level of $40 \mu \mathrm{m}$. In all tested cases there were observed also MAC (self-tempered martensite, retained austenite, carbide) phases on the small level of $3-5 \%$. Acicular ferrite with percentage above $57 \%$ was gettable only after micro-jet cooling (shown on Fig. 3, Tab. 4). Micro-jet gas pressure has strong influence on metallographic structure (Fig. 3).

After that the chemical analysis, micrograph tests and Charpy V impact test of the deposited metal were carried out. For these studies there were selected samples containing the highest acicular ferrite content (Table 4). The Charpy tests were 

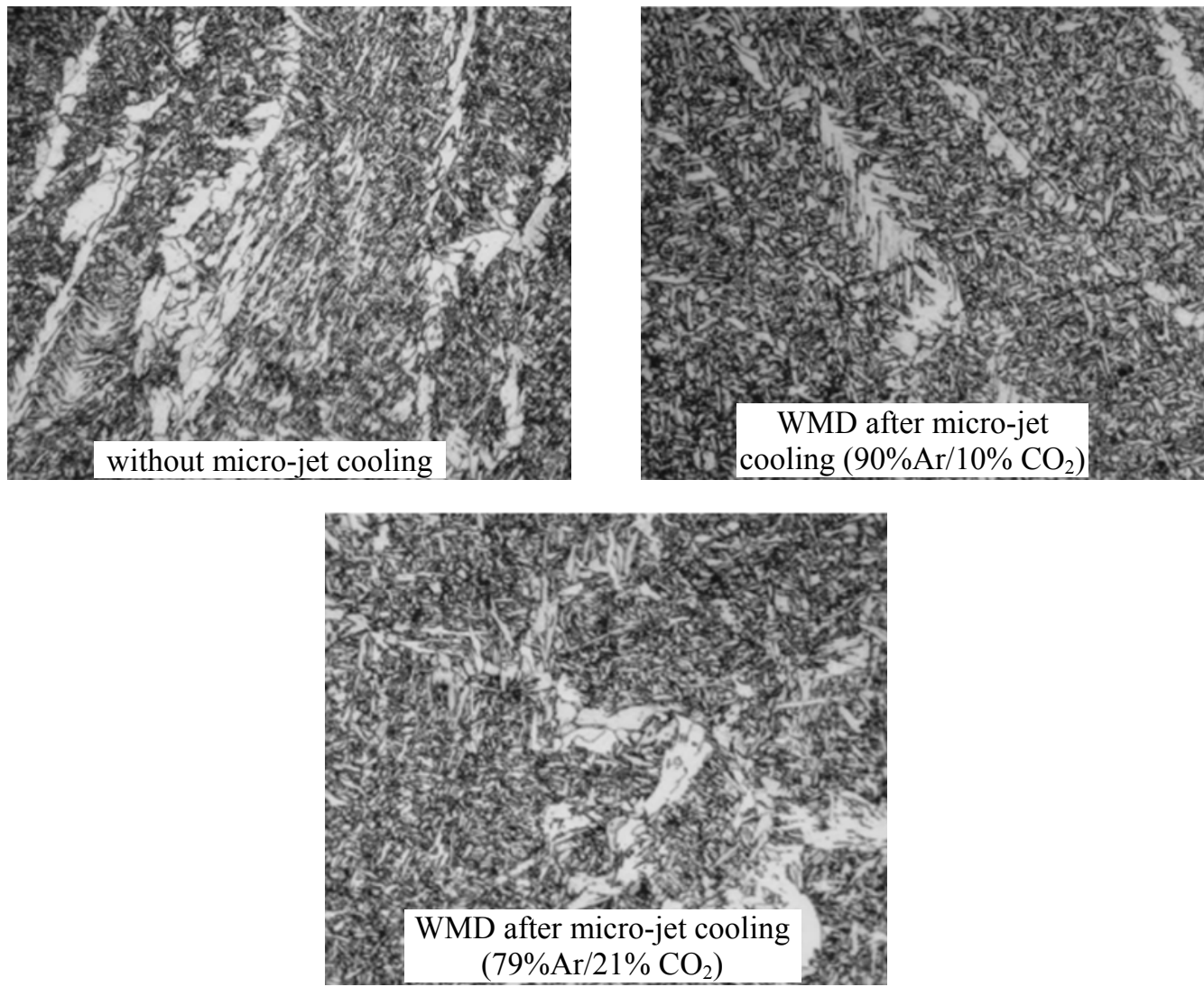

Fig. 3: Acicular ferrite in WMD (45-70\%)

done mainly at temperature $+20^{\circ} \mathrm{C}, 0$ and $-40^{\circ} \mathrm{C}$ on 5 specimens having been extracted from each weld metal (Tables 5-6).

TABLE 5

Impact toughness for MIG welding with varied micro-jet gases

\begin{tabular}{|c|c|c|}
\hline Micro-jet gas & \multirow{2}{*}{ Temp. $\left[{ }^{\circ} \mathbf{C}\right]$} & $\begin{array}{c}\text { Impact toughness } \\
{[\mathbf{K C V}, \mathbf{J}]}\end{array}$ \\
\hline $79 \% \mathrm{Ar}$ and $21 \% \mathrm{CO}_{2}$ & \multirow{2}{*}{40} & 47 \\
\cline { 1 - 1 } $90 \% \mathrm{Ar}$ and $10 \% \mathrm{O}_{2}$ & & 49 \\
\hline $79 \% \mathrm{Ar}$ and $21 \% \mathrm{CO}_{2}$ & \multirow{2}{*}{0} & 71 \\
\hline $90 \% \mathrm{Ar}$ and $10 \% \mathrm{O}_{2}$ & & 73 \\
\hline $79 \% \mathrm{Ar}$ and $21 \% \mathrm{CO}_{2}$ & \multirow{2}{*}{+20} & 177 \\
\hline $90 \% \mathrm{Ar}$ and $10 \% \mathrm{O}_{2}$ & & 180 \\
\hline
\end{tabular}

TABLE 6

Impact toughness for MAG welding with varied micro-jet gases

\begin{tabular}{|c|c|c|}
\hline \hline Micro-jet gas & \multirow{2}{*}{ Temp. $\left[{ }^{\circ} \mathbf{C}\right]$} & $\begin{array}{c}\text { Impact Toughness } \\
{[\mathbf{K C V}, \mathbf{J}]}\end{array}$ \\
\hline $79 \% \mathrm{Ar}$ and $21 \% \mathrm{CO}_{2}$ & \multirow{2}{*}{-40} & below 40 \\
\cline { 1 - 1 } $90 \% \mathrm{Ar}$ and $10 \% \mathrm{O}_{2}$ & & 47 \\
\hline $79 \% \mathrm{Ar}$ and $21 \% \mathrm{CO}_{2}$ & \multirow{2}{*}{0} & 66 \\
\hline $90 \% \mathrm{Ar}$ and $10 \% \mathrm{O}_{2}$ & & 69 \\
\hline $79 \% \mathrm{Ar}$ and $21 \% \mathrm{CO}_{2}$ & \multirow{2}{*}{+20} & 173 \\
\hline 90 & & 177 \\
\hline
\end{tabular}

It is possible to deduce that impact toughness at negative temperature of weld metal deposit is apparently affected by the kind of micro-jet gas mixture in cooling injector. Gas mix- tures of argon with carbon dioxide on the level of $10 \%$ could be regarded as a better choice. For the economic reasons gas mixture of argon with carbon dioxide could be recommended as a micro-jet cooling gas.

\section{Conclusions}

The micro-jet injector gives a real opportunity for professional development in the field of welding with controlling the parameters of weld structure. These investigation has proved that the new micro-jet technology has the potential for growth. It may be great achievement of welding technology in order to steer weld metal structure, impact toughness and strength. The new technology with micro-jet cooling may have many practical applications in many fields, like for example in automotive industry or to repair damaged metal elements. On the basis of investigation it is possible to deduce that:

- micro-jet cooling could be treated as an important element of MIG and MAG welding process;

- micro-jet cooling after welding can prove amount of ferrite $\mathrm{AF}$, the most beneficial phase in low alloy steel weld metal deposit;

- $\quad$ argon gas mixtures could be treated as an optimal micro-jet gas in welding process;

- $\quad$ micro-jet gas pressure should be on the level of $0.5 \mathrm{MPa}$;

- optimal micro-steam diameter should be on the level $40 \mu \mathrm{m}$. 


\section{REFERENCES}

[1] T. Węgrzyn, J. Mirosławski, A. Silva, D. Pinto, M. Miros, Oxide inclusions in steel welds of car body, Materials Science Forum 636-637, (2010).

[2] A. Lisiecki, Welding of titanium alloy by Disk laser. Proc. of SPIE, 8703, Laser Technology 2012: Applications of Lasers, 87030T (January 22, 2013), DOI: 10.1117/12.2013431, (2012).

[3] T. Wegrzyn, J. Piwnik, B. Łazarz, D. Hadrys, Main micro-jet cooling gases for steel welding, Archives of Metallurgy and Materials 58, (2013).

[4] B. Szczucka-Lasota, B. Formanek, A. Hernas, K Szymański: Oxidation models of the growth of corrosion products on the intermetallic coatings strengthened by a fine dispersive A12O3, Journal of Materials Processing Technology 164-165, (2005).

[5] G. Golański, J. Słania, Effect of different heat treatments on microstructure and mechanical properties of the martensitic GX12CrMoVNbN91 cast steel, Archives of Metallurgy and Materials 58, 1 (2013).

[6] J. Słania, Influence of phase transformations in the temperature ranges of $1250-1000^{\circ} \mathrm{C}$ and $650-350^{\circ} \mathrm{C}$ on the ferrite content in austenitic welds made with T 2312 LRM3 tubular electrode, Metallurgy and Materials 50, 3 (2005).

[7] T. Węgrzyn, Nucleation Of Acicular Ferrite At Oxide Inclusion Sites In Basic Electrode Steel Metal Weld Deposit, International Society of Offshore and Polar Engineers ISOPE'98, Montreal, Canada (1998).

[8] J. Piwnik, D. Hadryś, G. Skorulski, Plastic properties of weld after micro-jet cooling, Journal of Achievements in Materials and Manufacturing Engineering JAMME 59, (2013).

[9] Hadryś, J. Piwnik, W. Majewski, Plastic properties of welds after micro-jet cooling with different cooling gases. Advanced Materials Research 1036, (2014).

[10] R. Burdzik, Z. Stanik, J. Warczek, Method of assessing the impact of material properties on the propagation of vibrations excited with a single force impulse, Archives of Metallurgy and Materials 57, (2012).

[11] P. Czech, Diagnosis of industrial gearboxes condition by vibration and time-frequency, scale-frequency, frequency-frequency analysis. Metalurgija 4/51 (2012).

[12] H. Madej, P. Czech, Discrete wavelet transform and probabilistic neural network in ic engine fault diagnosis, Maintenance and Reliability 4 (2010). 